\title{
Editorial
}

\section{Repensando a Declaração Universal sobre Bioética e Direitos Humanos}

Para marcar os 10 anos de vigência da Declaração Universal sobre Bioética e Direitos Humanos, vale repensar seus princípios e diretrizes, reverenciando a dignidade humana, que só se consubstancia no viver em um ambiente social, político e econômico onde os valores éticos sejam aplicados no cotidiano.

A Conferência Geral da Organização das Nações Unidas para Educação, Ciência e Cultura (UNESCO), em outubro de 2005, adotou por aclamação a Declaração Universal sobre Bioética e Direitos Humanos, marco histórico, no qual os Estados-membros comprometeram-se, e a comunidade internacional, a respeitar e aplicar os princípios fundamentais da bioética condensados num texto único.

Tal declaração destaca que o progresso da ciência e da tecnologia pode gerar grandes benefícios para a humanidade, aumentando a esperança de vida, melhorando a sua qualidade, e que estes progressos deverão sempre procurar promover o bem-estar dos indivíduos, das famílias, dos grupos e das comunidades. Portanto, da humanidade em geral, no reconhecimento da dignidade da pessoa humana e no respeito universal e efetivo dos direitos humanos e das liberdades fundamentais1.

Propõe como um de seus objetivos reconhecer a importância da liberdade de investigação científica e dos benefícios decorrentes dos progressos da ciência e da tecnologia, salientando ao mesmo tempo a necessidade de que essa pesquisa e seus resultados atendam aos princípios éticos enunciados na referida Declaração ${ }^{1}$.

Para tanto, é imprescindível que as pessoas e as populações, a partir das conquistas do passado, se apropriem de seus destinos, determinando o presente e o futuro como consequências de suas decisões.

Em referência a estas conquistas, Bobbio² destaca que não precisamos da criação de mais direitos, antes, necessitamos da efetivação dos que já possuímos. A questão que se apresenta na atualidade é impedir a violação dos direitos humanos e corroborar para a sua plena concretude, alcançando todas as pessoas. Essa ideia é reforçada quando se destaca que "a justiça por sua própria natureza, tem de ter um alcance universal, em vez de ser aplicável aos problemas e dificuldades de algumas pessoas, mas não de outras"3:147.

Cabe aos profissionais/aos estudantes envolvidos nas práticas em saúde e na produção do conhecimento, dar a visibilidade necessária ao contexto moral e ético imprescindíveis nesse processo que tem o ser humano como centro desse fazer em todas as dimensões que promovem e dizem respeito ao bem viver em sociedade. Assim, a preocupação por tão nobre compromisso deve estar, também, voltada para causas humanas e relações sociais dos diferentes grupos populacionais.

Nesse contexto, a bioética cria um espaço de diálogo interdisciplinar, ou seja, de colaboração e interação de diferentes áreas de conhecimento e suas decisões não podem ser tomadas baseando-se, apenas, nos fatos do cotidiano que surgem no campo das práticas em saúde. Isto pode conduzir ao erro, pois é preciso levar em conta a singularidade das pessoas envolvidas nesse processo ${ }^{4}$.

Para tanto, é importante ressaltar um novo e característico imperativo categórico relacionado a um outro tipo de ação humana: Atue de tal forma que as consequências de tua ação correspondam a uma vida humana autêntica. Tal imperativo é de ordem racional, significando um agir coletivo como um bem público e não individual. Chama atenção para o Princípio da Responsabilidade que além de ser considerado um princípio ético, proporciona uma perspectiva de diálogo crítico em plena era tecnológica 5 .

Aspecto tão necessário quando se articula a Bioética aos Direitos Humanos e deve ser expresso nas diversas produções de conhecimento destacando-se de modo especial a vida, a saúde e o bem-estar dos seres humanos. Princípio da Responsabilidade implica ser, também, um imperativo da existência, pois essa seria a primeira condição ética e responsável com e para o mundo atual e do amanhã.

Afinal, respaldar-se na historicidade das conquistas ao longo dos tempos nos remete para o respeito ao ser humano que se dá pelo compromisso ético-moral e suas implicações para o exercício da cidadania. 
Neste sentido, a equidade e a justiça social devem fazer parte do debate importante e necessário para que se possa entender as contradições do que ocorre na atualidade e é preconizado pela Declaração Universal dos Direitos Humanos, e se constituem como princípios do Sistema Único de Saúde (SUS), portando direitos constitucionais.

Ambas, equidade e justiça social estão atreladas e devem fazer parte do agir ético tendo em vista que a ética e a bioética devem ter um caráter de universalidade, mas também de particularidade, aqui representadas pela sensibilidade de atentar para o contexto e para as características individuais. Assim, a bioética expressa a preocupação com a vida justa, que sempre o será em relação ao outro; a ética e a bioética são, portanto, relacionais ${ }^{6,7}$.

A Declaração Universal sobre Bioética e Direitos Humanos em todo o seu texto contempla uma questão extremamente cara à bioética no Brasil, a preocupação com a dignidade da pessoa humana e em particular com os vulneráveis face aos avanços tecnológicos, às desigualdades econômicas e, portanto, sociais. Nessa perspectiva, cabe mencionar Amartya Sen ${ }^{3}$ - "o que nos move, com muita sensatez, não é a compreensão de que o mundo é privado de uma justiça completa, mas a de que a nossa volta existem injustiças claramente remediáveis que queremos eliminar" $\$:$.

Cabe-nos, por conseguinte, o engajamento político e social na perspectiva de que o cerne das declaraçóes seja transformado em práxis, para isso, é importante considerar a posicionalidade, dos sujeitos, atores sociais. Destaca-se então que a posição original irá determinar sobre que prisma iremos perceber os direitos ou a violação destes, resultando em sua defesa em maior ou menor grau.

Vale ressair que os direitos humanos não se sustentam se não se tornarem direitos políticos, eles precisam estar escritos e não apenas fazer parte dos desejos da sociedade, de igual forma, "não são os direitos de humanos num estado de natureza; são os direitos de humanos em sociedade" ${ }^{2,8}$.

Esperamos que os resultados positivos dos estudos disseminados por esta Revista sejam compartilhados por profissionais de saúde e demais leitores em benefício da qualidade de vida de nossos clientes, familiares e consumidores.

\section{Benedita Maria Rêgo Deusdará Rodrigues} Conselheira Editorial

Patrícia Lima Pereira Peres

Professora Assistente do Departamento de Enfermagem Materno-Infantil da Faculdade de Enfermagem da Universidade do Estado do Rio de Janeiro

Araci Carmen Clos Editora Assistente

\section{REFERÊNCIAS}

1.Organização das Nações Unidas para a Educação, Ciência e Cultura (UNESCO). Declaração Universal sobre Bioética e Direitos Humanos. Portugal: UNESCO; 2006.

2.Bobbio, N. A era dos direitos.Rio de Janeiro: Campus Elsevier; 2004.

3.Sen, A. A ideia de Justiça. São Paulo: Companhia das Letras; 2011.

4.Rodrigues, BMRD, Peres, PLP, Pacheco, STA. Boas práticas de maternança na perspectiva bioética: uma contribuição para a enfermagem pediátrica. Rev enferm. UERJ. 2015; 23:567-571.

5.Honas, J. El principio del resposabilidad: ensayo de una ética para la civilizacion tecnologica. Barcelona: Herder; 1995. 6.Pegoraro, AO. Ética é Justiça. Petrópolis: Editora Vozes; 1999.

7.Pegoraro, AO. Ética e Bioética: Da subsistência à existência. 2ª Ed. Petrópolis: Vozes; 2010.

8.Hunt, L. A invenção dos Direitos Humanos - Uma história. São Paulo: Companhia das Letras; 2009. 